\title{
Formulation and Characterization of Ziprasidone Floating Pellets
}

\section{J Praveen Kumar ${ }^{1}$, S Harika ${ }^{2}$}

\author{
${ }^{1}$ Associate Professor, Department of Pharmaceutics, Krishna Teja Pharmacy College, Tirupati- \\ 517506, Chittoor Dist, Andhra Pradesh. \\ ${ }^{2}$ Department of Pharmaceutics, Krishna Teja Pharmacy College, Tirupati-517506, Chittoor \\ Dist., Andhra Pradesh.
}

Article Info: Received 15 December 2019; Accepted 04 January. 2020

DOI: https://doi.org/10.32553/jbpr.v11i1.894

Address for Correspondence: J Praveen Kumar

Conflict of interest statement: No conflict of interest

\section{ABSTRACT:}

The objective of this study is to design and evaluate Ziprasidone Floating pellets, which prolongs the release rate of the drug while extending the residence time of the drug within the body environment and without causing undeliterious effects to the subject. Ziprasidone and controlled matrix polymer granules were prepared by different granulation techniques in the ratio of 1:1, 1:1.5 and 1:2.Ziprasidone multi unit formulations comprising cellulose polymers were prepared by wet granulation technique, where as the Ziprasidone multi unit formulations comprising lipoidal / fatty polymers were prepared by melt granulation technique. Ziprasidone multi unit formulations with drug and polymer proportion as 1:1, F1 and F2 formulations consisting Cellulose polymers HPMC K4M and HPMC K100 respectively were prepared by wet granulation technique.

Keywords: Ziprasidone, wet granulation, Floating pellets, melt granulation and polymer.

\section{INTRODUCTION}

Ziprasidone is a psychotropic agent belonging to the chemical class of benzisoxazole .

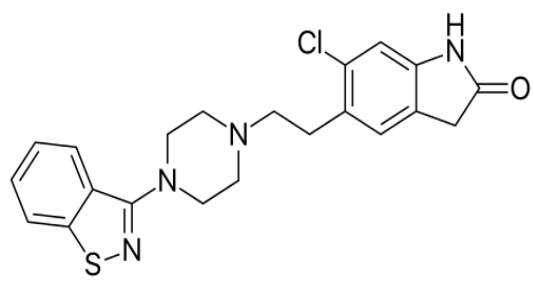

$\mathrm{C}_{21} \mathrm{H}_{21} \mathrm{ClN}_{4} \mathrm{OS}$ 5-[2-[4-(1, 2-benzothiazol-3-yl) piperazin-1-yl] ethyl]-6-chloro-1, 3dihydroindol-2-one.Ziprasidone functions as an antagonist at the dopamine D2 and serotonin 5HT2A and 5-HT1D receptors, and as an agonist at the 5-HT1A receptor. Ziprasidone also inhibits the synaptic reuptake of serotonin and norepinephrine. The mechanism of action by which Ziprasidone exerts its antischizophrenic effect is unknown but is potentially mediated through a combination of dopamine D2 and serotonin 5-HT2 antagonism. In the absence of food, ziprasidone's oral bioavailability is $60 \%$, and absorption may reach $100 \%$ if ziprasidone is taken with a meal containing at least $500 \mathrm{kcal}$.The mean apparent volume of distribution of Ziprasidone is 1.5 $\mathrm{L} / \mathrm{kg}$.It is extensively protein bound with over $99 \%$ of the drug bound to plasma proteins, primarily albumin and alpha1-acid glycoprotein. The half life of ziprasidone is 6-7 hours. The present work was carried with an in house experimental design to prepare multi unit granule GFDDS employing successful cellulose 
polymers and various efficient lipoidal/fatty polymers with a motto to optimize best polymer among all of them for formulation of hydrodynamically balanced floating drug delivery system of Ziprasidone

\section{FORMULATION DEVELOPMENT}

Ziprasidone and controlled matrix polymer granules were prepared by different granulation techniques in the ratio of $1: 1,1: 1.5$ and 1:2.Ziprasidone multi unit formulations comprising cellulose polymers were prepared by wet granulation technique, where as the Ziprasidone multi unit formulations comprising lipoidal / fatty polymers were prepared by melt granulation technique. Ziprasidone multi unit formulations with drug and polymer proportion as 1:1, F1 and F2 formulations consisting Cellulose polymers HPMC K4M and HPMC K100 respectively were prepared by wet granulation technique.

\section{PREPARATION OF ZIPRASIDONE MULTI UNIT GFDDS BY WET GRANULATION TECHNIQUE}

1. Drug and polymer were weighed according to the experimental design, were passed through 40 \# sieve separately and blended thoroughly.

2. The blend was granulated with PVP K30 solution which was prepared by dissolving PVP K30 in Iso propyl alcohol.

3. The wet mass was passed through $16 \#$ sieve and dried at $65^{\circ} \mathrm{C}$ for one hour.

Ziprasidone multi unit formulations with drug and polymer proportion as 1:1, and formulations consisting lipoidal / fatty polymers i.e., Compritol 888 and Gelucire 43/01 were prepared by melt granulation technique.

\section{PREPARATION OF ZIPRASIDONE MULTI UNIT GFDDS BY MELT GRANULATION TECHNIQUE}

1. Drug and the polymer were weighed according to the experimental design.

2. The lipoidal polymer was taken into a beaker and melted above $5^{\circ} \mathrm{C}$ of their corresponding melting points.

3. Drug that is priorly passed through $40 \#$ sieve was dispersed in the polymer melt by continuous agitation.

4. Drug dispersed melt was allowed to solidify at $4^{\circ} \mathrm{C}$.

5. The solidified mass was passed through $16 \#$ sieve to attain uniform sized granules.

Table: 1. Compositions of Formulations F1-F12

DRUG : POLYMER PROPORTION - 1: 1, 1:1.5 \&1:2

\begin{tabular}{|c|c|c|c|c|c|c|c|c|c|c|c|c|}
\hline FORMULA & $\begin{array}{l}\text { F 1 } \\
\text { (mg) }\end{array}$ & $\begin{array}{l}\text { F } 2 \\
\text { (mg) }\end{array}$ & $\begin{array}{l}\text { F 3 } \\
\text { (mg) }\end{array}$ & $\begin{array}{l}\text { F } 4 \\
\text { (mg) }\end{array}$ & 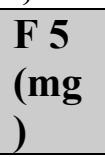 & 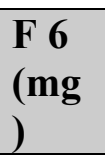 & $\begin{array}{l}\text { F 7 } \\
\text { (mg } \\
\text { ) }\end{array}$ & $\begin{array}{l}\text { F } 8 \\
\text { (mg } \\
)\end{array}$ & $\begin{array}{l}\text { F 9 } \\
\text { (mg } \\
\text { ) }\end{array}$ & $\begin{array}{l}\text { F 10 } \\
\text { (mg } \\
\text { ) }\end{array}$ & $\begin{array}{l}\text { F } 11 \\
\text { (mg } \\
\text { ) }\end{array}$ & $\begin{array}{l}\text { F 12 } \\
\text { (mg } \\
\text { ) }\end{array}$ \\
\hline $\begin{array}{l}\text { Ziprasidon } \\
\text { e }\end{array}$ & 80 & 80 & 80 & 80 & 80 & 80 & 80 & 80 & 80 & 80 & 80 & 80 \\
\hline $\begin{array}{l}\text { HPMC } \\
\text { K4M }\end{array}$ & 80 & -- & -- & -- & 120 & -- & -- & -- & 160 & -- & -- & -- \\
\hline $\begin{array}{l}\text { HPMC } \\
\text { K100 }\end{array}$ & -- & 80 & -- & -- & -- & 120 & -- & -- & -- & 160 & -- & -- \\
\hline $\begin{array}{l}\text { Compritol } \\
888 \text { ATO }\end{array}$ & -- & -- & 80 & -- & -- & -- & 120 & -- & -- & -- & 160 & -- \\
\hline $\begin{array}{l}\text { Gelucire } \\
43 / 01\end{array}$ & -- & -- & -- & 80 & -- & -- & -- & 120 & -- & -- & -- & 160 \\
\hline
\end{tabular}

Ziprasidone multi unit formulations with drug and polymer proportion as 1:1.5, F5 and F6 formulations and with drug and polymer proportion as 1: 2, F9 and F10 formulations 
consisting Cellulose polymers HPMC K4M and HPMC K100 respectively were prepared by wet granulation technique. Ziprasidone multi unit formulations with drug and polymer proportion as 1:1.5, F7 and F8 formulations and with drug and polymer proportion as $1: 2, \mathrm{~F} 11$ and F12 formulations consisting lipoidal / fatty polymers i.e., Compritol 888 ATO, and Gelucire 43/01 were prepared by melt granulation technique.

\section{PREPARATION OF STANDARD SOLUTION FOR STANDARD GRAPH}

$100 \mathrm{mg}$ of Ziprasidone was accurately weighed and taken into a $100 \mathrm{ml}$ volumetric flask, to this $1.2 \mathrm{pH} \mathrm{HCl}$ was added to dissolve the drug and volume was made up to $100 \mathrm{ml}$ with $1.2 \mathrm{pH} \mathrm{HCl}$ and mixed, necessary dilutions were made to give concentration of Ziprasidone ranging from 2 to $10 \mu \mathrm{g} / \mathrm{ml}$ solutions.

\section{METHOD FOR STANDARD PLOT OF ZIPRASIDONE}

The volumetric solutions were scanned in a UVVisible spectrophotometer to determine the $\lambda$ $\max (318 \mathrm{~nm})$ of the drug. The absorbance of the volumetric solutions was recorded at $\lambda$ max of the drug and plotted graphically to give the standard graph of Ziprasidone.

\section{STANDARD PLOT OF ZIPRASIDONE}

The standard graph of Ziprasidone in $0.1 \mathrm{~N} \mathrm{HCl}$ showed a good linearity with $\mathrm{R}^{2}$ of 0.9993 , in the concentration range of $2-10 \mu \mathrm{g} / \mathrm{ml}$. The pharmaceutical compositions are designed as multi units, to be more suitable because they claim to reduce the intersubject variability in absorption and lower the probability of dose dumping.Ziprasidone and controlled matrix polymer granules were prepared by different granulation techniques in the ratio of 1:1, 1:1.5 and 1:2. Ziprasidone multi unit formulations with drug and polymer proportion as 1:1, F1 and F2 formulations consisting Cellulose polymers HPMC K4M and HPMC K100 respectively were prepared by wet granulation technique.

Table: 2. Standard Plot Values of Ziprasidone at $318 \mathrm{~nm}$

\begin{tabular}{|l|l|}
\hline CONCENTRATION $(\boldsymbol{\mu g} / \mathbf{m l})$ & ABSORBANCE \\
\hline 0 & 0 \\
\hline 2 & 0.084 \\
\hline 4 & 0.183 \\
\hline 6 & 0.273 \\
\hline 8 & 0.364 \\
\hline 10 & 0.468 \\
\hline
\end{tabular}

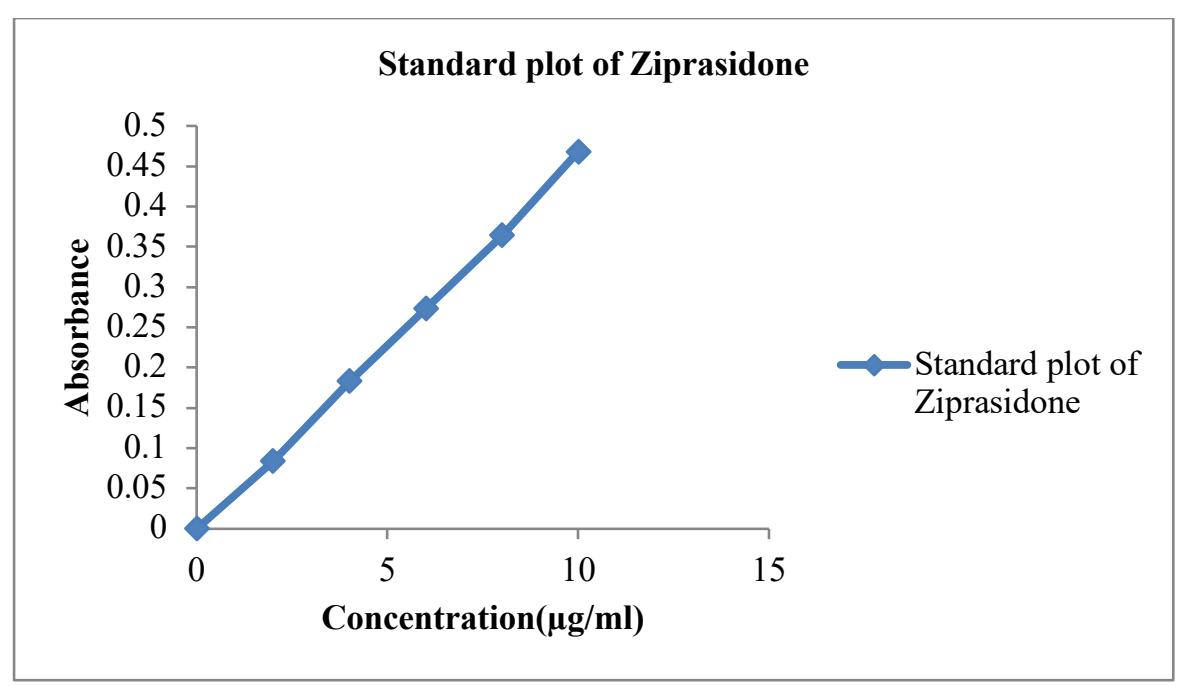

Figure 1: Standard Plot of Ziprasidone at $318 \mathbf{n m}$ 
Ziprasidone multi unit formulations with drug and polymer proportion as $1: 1, \mathrm{~F} 3$ and F4 formulations consisting lipoidal / fatty polymers i.e., Compritol 888 ATO and Gelucire 43/01 were prepared by melt granulation technique.The drug content estimated was found to be within the specified limits i.e., less than \pm $5 \%$ variation of the stated amount of Ziprasidone. All the multi unit granule GFDDS were evaluated for the physical parameters like Bulk density, Tapped density, Compressibility Index, Hausner ratio and Angle of repose. Granules comprising cellulose polymers has shown good flow properties where as granules comprising lipoidal polymers has shown results inferior to that of cellulose polymers as they are prepared by melt granulation technique, but are passable.

Table: 3. Assay values of the prepared formulations

\begin{tabular}{|l|l|}
\hline FORMULATION & DRUG CONTENT (\%) \\
\hline F1 & 98.23 \\
\hline F2 & 99.65 \\
\hline F3 & 99.12 \\
\hline F4 & 98.44 \\
\hline F5 & 99.23 \\
\hline F6 & 98.63 \\
\hline F7 & 99.65 \\
\hline F8 & 98.65 \\
\hline F9 & 98.45 \\
\hline F10 & 99.64 \\
\hline F11 & 98.12 \\
\hline F12 & 99.72 \\
\hline
\end{tabular}

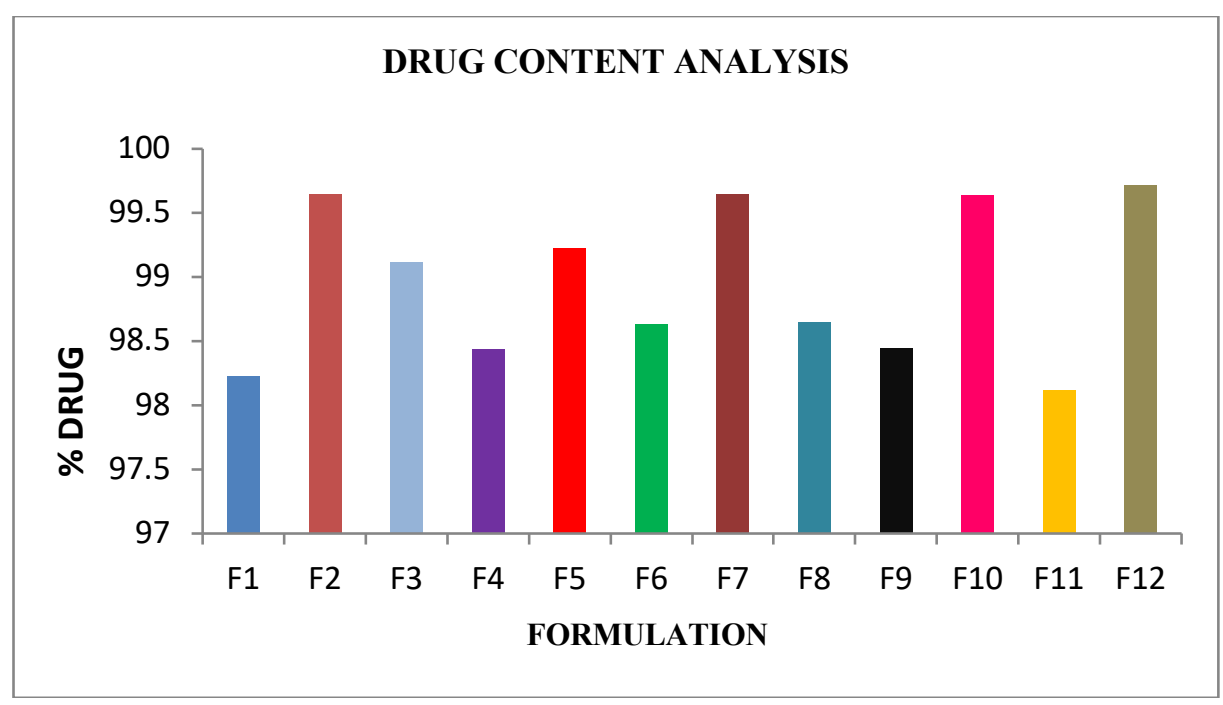

Figure 2: Assay values of the prepared formulations 
Table 4: Flow properties of the prepared formulations

\begin{tabular}{|l|l|}
\hline FORMULATION & ANGLE OF REPOSE \\
\hline F1 & $20.6^{\circ}$ \\
\hline F2 & $23.5^{\circ}$ \\
\hline F3 & $31.2^{\circ}$ \\
\hline F4 & $30.7^{\circ}$ \\
\hline F5 & $26.8^{\circ}$ \\
\hline F6 & $33.1^{\circ}$ \\
\hline F7 & $32.8^{\circ}$ \\
\hline F8 & $20.9^{\circ}$ \\
\hline F9 & $24.2^{\circ}$ \\
\hline F10 & $31.7^{\circ}$ \\
\hline F11 & $31.2^{\circ}$ \\
\hline F12 & $30.8^{\circ}$ \\
\hline
\end{tabular}

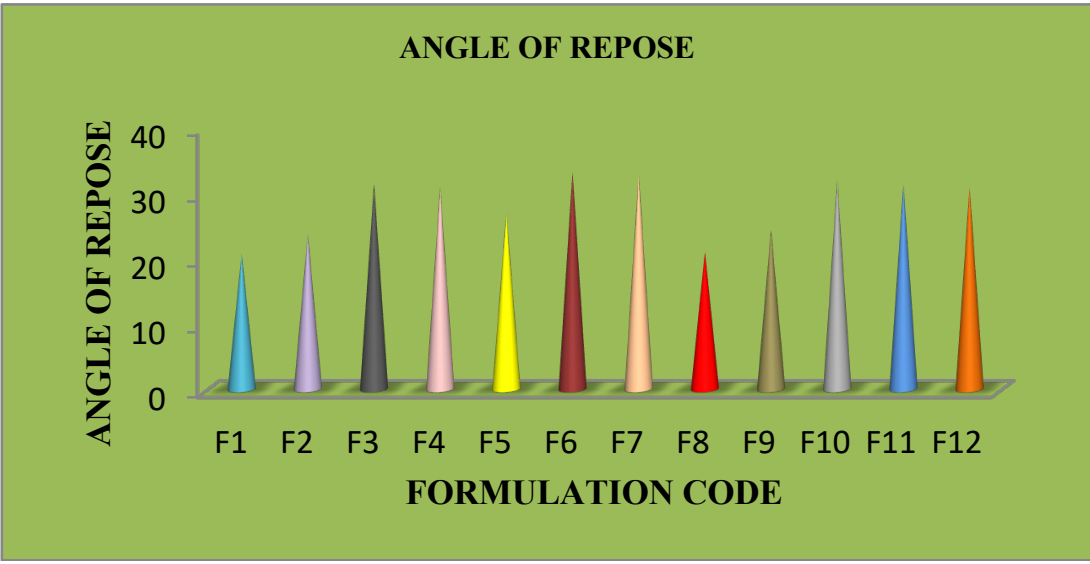

Figure 3: Flow properties of the prepared formulations

The entire prepared multi unit granule GFFDS were subjected to in vitro buoyancy studies that are carried out in $0.1 \mathrm{~N} \mathrm{HCl}$. All the formulations F1-F12 were tested for floating parameters like Floating lag time and floating duration time

Table 5: Invitro Buoyancy Results of Prepared Formulations

\begin{tabular}{|l|l|l|}
\hline Formula & Buoyancy Lag Time (Min) & Duration of Floating (Hrs) \\
\hline F1 & $20 \mathrm{~min}$ & $>12$ \\
\hline F2 & $35 \mathrm{~min}$ & $>12$ \\
\hline F3 & --- & $>12(10-20 \%) \downarrow$ \\
\hline F4 & --- & $>12$ \\
\hline F5 & --- & $>12$ \\
\hline F6 & --- & $>12$ \\
\hline F7 & --- & $>12(10-20 \%) \downarrow$ \\
\hline F8 & $25 \min$ & $>12$ \\
\hline F9 & $42 \min$ & $>12$ \\
\hline F10 & --- & $>12$ \\
\hline F11 & --- & $2(60 \%) \downarrow$ \\
\hline F12 & --- & $>19$ \\
\hline
\end{tabular}


Formulations prepared with cellulose polymers in different drug to polymer proportions ( $\mathrm{F} 1, \mathrm{~F} 2$, F5, F6, F9, F10) had shown buoyancy lag time which might be the time taken for hydrogel formation, where as all the other formulations prepared with lipoidal polymers in different drug to polymer proportions had floated from zero time. But in case of multi unit formulations prepared with Compritol 888 ATO 10-20\% and $60 \%$ of granules respectively had shrinked to the bottom after 2 hours. Other multi unit GFDDS prepared with Gelucire 43/01 had shown excellent buoyancy characteristics beyond 12 hours of study.

Table: 6. Cumulative \% release of Formulations F1-F4

\begin{tabular}{|l|l|l|l|l|}
\hline $\begin{array}{l}\text { Time } \\
\text { (Hrs) }\end{array}$ & F1 & F2 & F3 & F4 \\
\hline 0 & 0 & 0 & 0 & 0 \\
\hline 0.5 & $10.52 \pm 1.50$ & $13.37 \pm 1.20$ & $26.62 \pm 1.75$ & $4.17 \pm 1.02$ \\
\hline 1 & $15.31 \pm 0.75$ & $28.15 \pm 0.89$ & $33.74 \pm 1.64$ & $8.11 \pm 1.45$ \\
\hline 1.5 & $22.34 \pm 0.68$ & $41.22 \pm 0.86$ & $42.17 \pm 0.84$ & $13.13 \pm 0.12$ \\
\hline 2 & $38.73 \pm 1.22$ & $59.05 \pm 0.64$ & $51.64 \pm 1.26$ & $17.43 \pm 0.65$ \\
\hline 3 & $57.22 \pm 1.44$ & $71.29 \pm 1.23$ & $63.21 \pm 0.92$ & $26.28 \pm 1.45$ \\
\hline 4 & $65.29 \pm 0.69$ & $82.38 \pm 1.44$ & $71.4 \pm 0.35$ & $35.34 \pm 1.79$ \\
\hline 5 & $86.03 \pm 0.98$ & $96.82 \pm 1.28$ & $79.32 \pm 0.46$ & $47.66 \pm 1.34$ \\
\hline 6 & $95.07 \pm 1.10$ & & $86.47 \pm 1.25$ & $62.6 \pm 0.15$ \\
\hline 8 & & & $98.61 \pm 0.24$ & $73.47 \pm 0.49$ \\
\hline 10 & & & & $87.32 \pm 0.97$ \\
\hline 12 & & & & $98.96 \pm 0.84$ \\
\hline
\end{tabular}

$\operatorname{MEAN} \pm$ S.D $n=3$

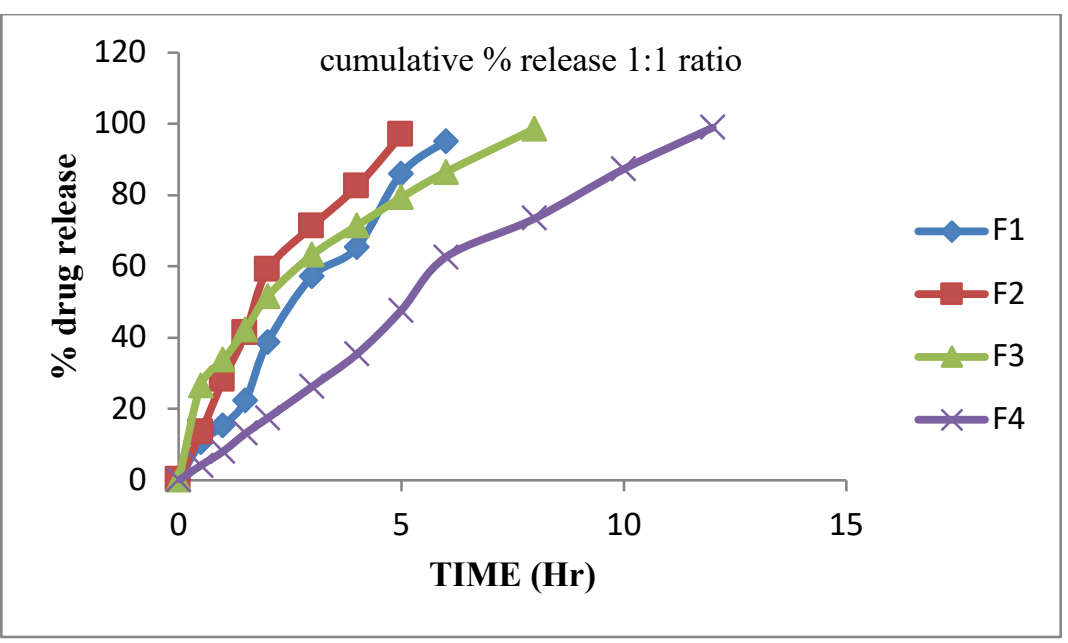

Figure 4: Comparative Dissolution Profiles of Formulations F1-F4 
Table 7: Cumulative \% release of Formulations F5-F8

\begin{tabular}{|l|l|l|l|l|}
\hline $\begin{array}{l}\text { Time } \\
\text { (Hrs) }\end{array}$ & F5 & F6 & F7 & F8 \\
\hline $\mathbf{0}$ & 0 & 0 & 0 & 0 \\
\hline $\mathbf{0 . 5}$ & $9.74 \pm 0.94$ & $11.43 \pm 1.76$ & $6.23 \pm 1.28$ & $2.15 \pm 1.48$ \\
\hline $\mathbf{1}$ & $13.81 \pm 1.48$ & $23.31 \pm 1.34$ & $10.56 \pm 1.46$ & $4.47 \pm 1.46$ \\
\hline $\mathbf{1 . 5}$ & $20.31 \pm 1.78$ & $37.4 \pm 0.18$ & $16.19 \pm 1.28$ & $9.84 \pm 1.79$ \\
\hline $\mathbf{2}$ & $34.74 \pm 0.18$ & $51.62 \pm 0.49$ & $26.23 \pm 1.26$ & $12.29 \pm 0.48$ \\
\hline $\mathbf{3}$ & $43.29 \pm 0.64$ & $64.17 \pm 1.26$ & $39.26 \pm 1.34$ & $18.21 \pm 0.94$ \\
\hline $\mathbf{4}$ & $55.57 \pm 1.97$ & $72.39 \pm 1.28$ & $48.63 \pm 0.24$ & $24.93 \pm 0.87$ \\
\hline $\mathbf{5}$ & $63.36 \pm 1.46$ & $81.2 \pm 0.48$ & $56.66 \pm 0.97$ & $33.36 \pm 0.89$ \\
\hline $\mathbf{6}$ & $71.28 \pm 1.87$ & $95.51 \pm 1.49$ & $64.63 \pm 0.67$ & $43.49 \pm 1.87$ \\
\hline $\mathbf{8}$ & $83.11 \pm 0.48$ & & $77.34 \pm 1.48$ & $49.21 \pm 1.26$ \\
\hline $\mathbf{1 0}$ & $93.27 \pm 1.34$ & & $85.76 \pm 0.67$ & $55.59 \pm 1.48$ \\
\hline $\mathbf{1 2}$ & & & $92.28 \pm 0.42$ & $62.93 \pm 0.54$ \\
\hline
\end{tabular}

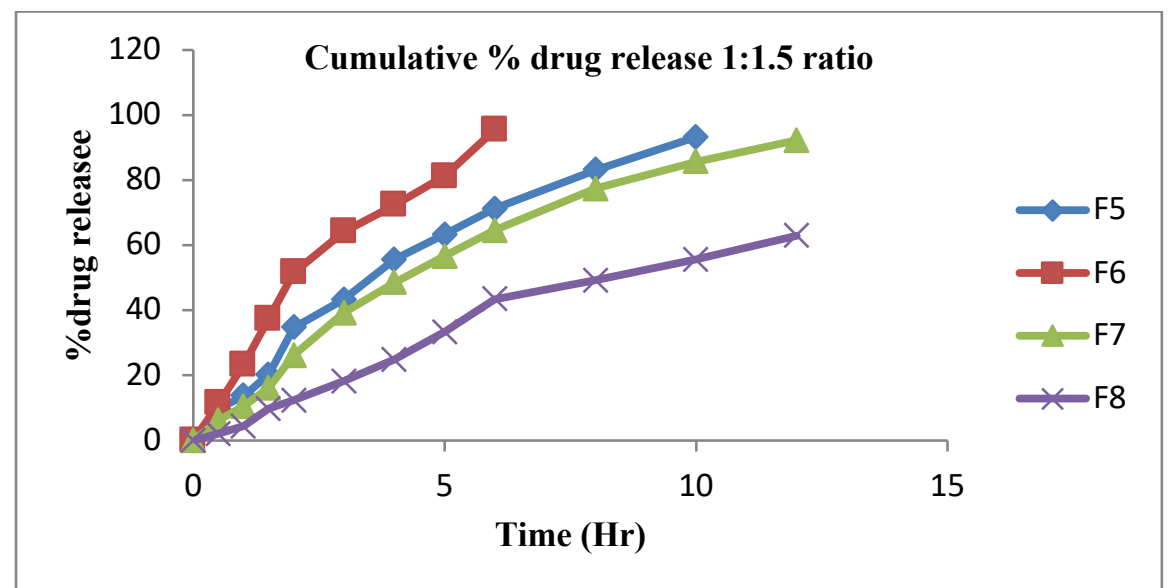

Figure 5: Comparative Dissolution Profiles of Formulations F5-F8

Table 8: Cumulative \% release of Formulations F9-F12

\begin{tabular}{|l|l|l|l|l|}
\hline Time (Hrs) & F9 & F10 & F11 & F12 \\
\hline $\mathbf{0}$ & 0 & 0 & 0 & 0 \\
\hline $\mathbf{0 . 5}$ & $5.63 \pm 1.72$ & $10.41 \pm 1.25$ & $4.24 \pm 1.32$ & $3.23 \pm 1.26$ \\
\hline $\mathbf{1}$ & $9.94 \pm 2.34$ & $19.62 \pm 1.75$ & $8.82 \pm 1.56$ & $6.48 \pm 0.64$ \\
\hline $\mathbf{1 . 5}$ & $14.31 \pm 1.69$ & $31.53 \pm 2.76$ & $13.87 \pm 0.24$ & $8.59 \pm 2.22$ \\
\hline $\mathbf{2}$ & $21.16 \pm 0.84$ & $43.6 \pm 0.48$ & $19.39 \pm 0.65$ & $11.96 \pm 0.84$ \\
\hline $\mathbf{3}$ & $30.42 \pm 0.97$ & $52.77 \pm 0.29$ & $23.93 \pm 1.24$ & $17.59 \pm 0.91$ \\
\hline $\mathbf{4}$ & $39.63 \pm 1.12$ & $64.31 \pm 1.64$ & $34.42 \pm 2.01$ & $23.54 \pm 1.12$ \\
\hline $\mathbf{5}$ & $45.51 \pm 0.78$ & $76.56 \pm 1.35$ & $47.31 \pm 1.34$ & $29.89 \pm 1.35$ \\
\hline $\mathbf{6}$ & $56.05 \pm 0.11$ & $85.19 \pm 0.92$ & $59.2 \pm 1.56$ & $36.38 \pm 0.98$ \\
\hline $\mathbf{8}$ & $63.37 \pm 0.32$ & $98.23 \pm 1.21$ & $65.12 \pm 0.95$ & $40.54 \pm 1.23$ \\
\hline $\mathbf{1 0}$ & $74.4 \pm 1.44$ & & $73.37 \pm 0.32$ & $44.73 \pm 0.86$ \\
\hline $\mathbf{1 2}$ & $83.37 \pm 0.24$ & & $87.11 \pm 1.47$ & $49.77 \pm 1.44$ \\
\hline
\end{tabular}

$\operatorname{MEAN} \pm \operatorname{S} . \mathrm{D} n=3$ 


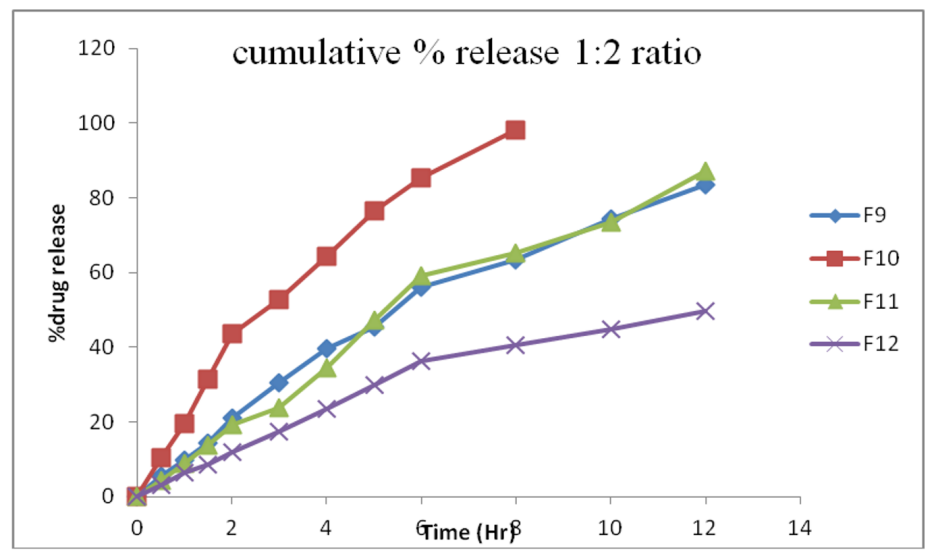

Figure 6: Comparative Dissolution Profiles of Formulations F9-F12

The in vitro drug release studies of the entire prepared multi unit GFDDS were studied separately according to their proportions $(1: 1,1: 1.5$ and 1:2) using $0.1 \mathrm{~N} \mathrm{HCl}$ as medium in USP XXIV paddle type dissolution apparatus.

Table 9: Cumulative \% release of Single Unit Formulation

\begin{tabular}{|l|l|}
\hline Time (Hrs) & SINGLE UNIT \\
\hline $\mathbf{0}$ & 0 \\
\hline $\mathbf{0 . 5}$ & $2.43 \pm 1.28$ \\
\hline $\mathbf{1}$ & $5.58 \pm 0.91$ \\
\hline $\mathbf{1 . 5}$ & $9.07 \pm 2.06$ \\
\hline $\mathbf{2}$ & $16 \pm 0.78$ \\
\hline $\mathbf{3}$ & $27.51 \pm 1.74$ \\
\hline $\mathbf{4}$ & $36.12 \pm 0.86$ \\
\hline $\mathbf{5}$ & $43.57 \pm 0.71$ \\
\hline $\mathbf{6}$ & $57.66 \pm 0.68$ \\
\hline $\mathbf{8}$ & $64.24 \pm 1.22$ \\
\hline $\mathbf{1 0}$ & $70.58 \pm 0.98$ \\
\hline $\mathbf{1 2}$ & $81.09 \pm 0.68$ \\
\hline
\end{tabular}

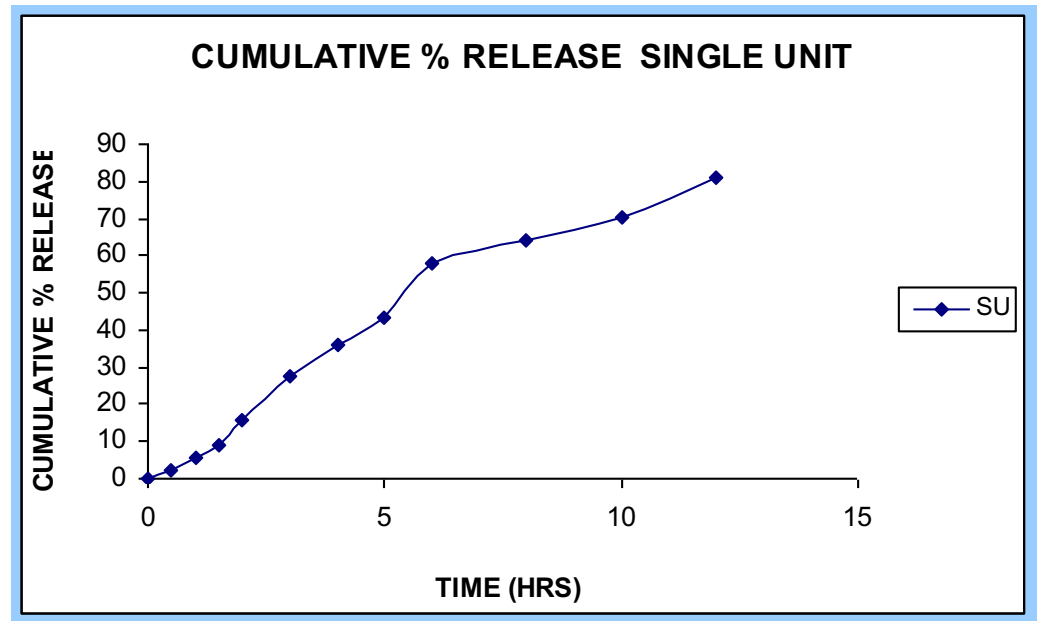

Figure 7: Dissolution Profile of Single Unit Formulation 
The dissolution characteristics of optimized multi unit formulation F7 is compared with that of the pure drug and Marketed formulation (Zeldox). Pure drug had shown its high hydrophilic characteristics by releasing $93 \%$ of drug in 0.5 hours itself, where as Ziprasidone marketed formulation had shown drug release of more than $97 \%$ in 1 hour.

Table 10: Cumulative \% release of Formulations F7, Zeldox, Pure Drug

\begin{tabular}{|l|l|l|l|}
\hline Time (Hrs) & F4 & ZELDOX & PURE DRUG \\
\hline $\mathbf{0}$ & 0 & 0 & 0 \\
\hline $\mathbf{0 . 5}$ & $4.17 \pm 1.02$ & $61.53 \pm 2.06$ & $93.37 \pm 2.02$ \\
\hline $\mathbf{1}$ & $8.11 \pm 1.45$ & $97.81 \pm 1.49$ & \\
\hline $\mathbf{1 . 5}$ & $13.13 \pm 0.12$ & & \\
\hline $\mathbf{2}$ & $17.43 \pm 0.65$ & & \\
\hline $\mathbf{3}$ & $26.28 \pm 1.45$ & & \\
\hline $\mathbf{4}$ & $35.34 \pm 1.79$ & & \\
\hline $\mathbf{5}$ & $47.66 \pm 1.34$ & & \\
\hline $\mathbf{6}$ & $62.6 \pm 0.15$ & & \\
\hline $\mathbf{8}$ & $73.47 \pm 0.49$ & & \\
\hline $\mathbf{1 0}$ & $87.32 \pm 0.97$ & & \\
\hline $\mathbf{1 2}$ & $98.96 \pm 0.84$ & & \\
\hline
\end{tabular}

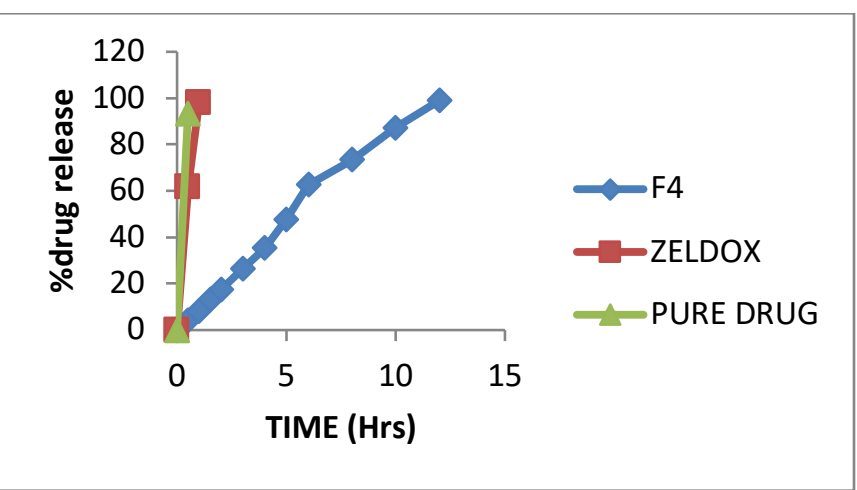

Figure 8: Comparative Dissolution Profiles of Formulations F4, Single Unit Formulation, Zeldox, Pure Drug

\section{DRUG RELEASE KINETICS}

In order to establish the mechanism of drug release, the experimental data was fitted to five popular exponential equations.

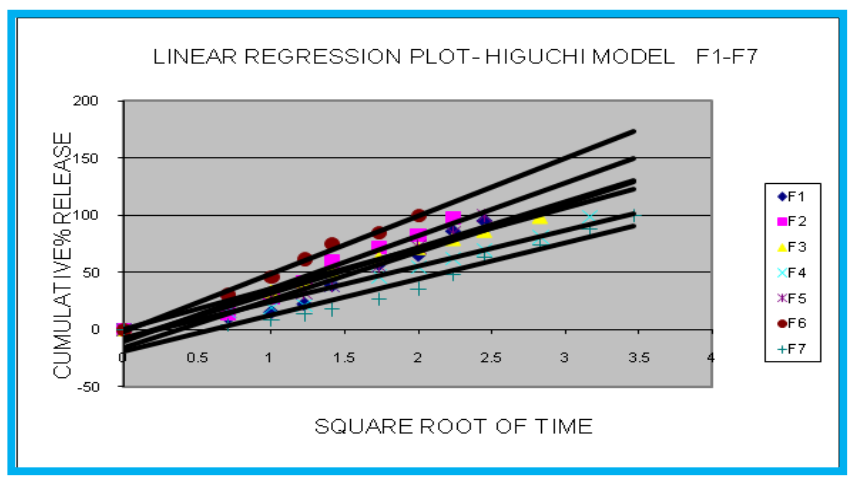


Figure 9: Linear Regression Plots for the Dissolution profiles of Ziprasidone Multi Unit GFDDS (Drug: Polymer - 1:1) Higuchi Plot

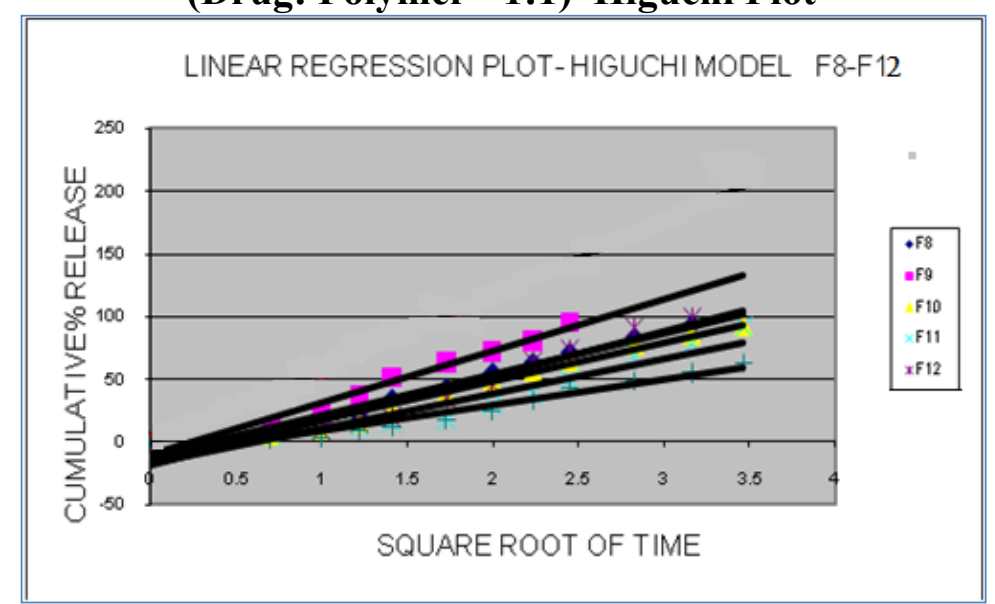

Figure 10: Linear Regression Plots for the Dissolution profiles of Ziprasidone Multi Unit GFDDS (Drug: Polymer - 1:1.5) Higuchi Plot

Table: 11. Correlation Coefficient (r) values and Release kinetics of Ziprasidone Multi Unit GFDDS (Drug to polymer proportion- 1:1) with Single unit, Marketed sample "Zeldox" and

Pure Drug

\begin{tabular}{|c|c|c|c|c|c|c|c|c|c|c|}
\hline \multirow[t]{2}{*}{ Formulation } & \multicolumn{2}{|c|}{ Zero Order } & \multicolumn{2}{|c|}{ First Order } & \multirow{2}{*}{$\begin{array}{l}\text { Diffusion } \\
\mathbf{R} \\
\end{array}$} & \multirow{2}{*}{$\begin{array}{l}\text { Erosion } \\
\mathbf{R} \\
\end{array}$} & \multicolumn{2}{|c|}{ Pappas Equation } & \multirow{2}{*}{$\begin{array}{l}\text { T }_{50} \\
\text { ( Hours) }\end{array}$} & \multirow{2}{*}{$\begin{array}{l}T_{80} \\
\text { ( Hours) }\end{array}$} \\
\hline & $\mathbf{K}_{\mathbf{O}}$ & $\mathbf{R}$ & $K_{1}$ & $\mathbf{R}$ & & & $\mathbf{R}$ & $\mathbf{N}$ & & \\
\hline F1 & 37.58 & 0.973 & 0.122 & 0.028 & 0.923 & 0.035 & 0.67 & 1.73 & 2.5 & 4.5 \\
\hline F2 & 44.01 & 0.956 & 0.158 & 0.030 & 0.962 & 0.025 & 0.507 & 1.75 & 1.8 & 3.8 \\
\hline $\mathbf{F 3}$ & 25.42 & 0.905 & 0.207 & 0.123 & 0.988 & 0.090 & 0.47 & 1.26 & 1.9 & 5.2 \\
\hline F4 & 21.07 & 0.956 & 0.145 & 0.098 & 0.975 & 0.086 & 0.61 & 1.25 & 3.5 & 8 \\
\hline F5 & 35.16 & 0.981 & 0.377 & 0.907 & 0.953 & 0.077 & 0.54 & 1.54 & 2.5 & 4.5 \\
\hline F6 & 52.87 & 0.906 & 0.384 & 0.087 & 0.972 & 0.028 & 0.40 & 1.95 & 1.2 & 2.5 \\
\hline F7 & 19.96 & 0.987 & 0.181 & 1.851 & 0.995 & 0.161 & 0.81 & 1.36 & 4.5 & 9 \\
\hline Single Unit & 16.60 & 0.962 & 0.089 & 0.99 & 0.946 & 0.003 & 0.975 & 1.992 & 5.5 & 11.8 \\
\hline Pure Drug & 428.9 & 1 & 5.435 & 1 & 1 & 1 & 0.996 & 1.187 & 0.3 & 0.75 \\
\hline ZELDOX & 225.25 & 0.971 & 0.221 & 0.92 & 0.992 & 0.49 & 0.993 & 1.196 & 0.1 & 0.4 \\
\hline
\end{tabular}

Table: 12. Correlation Coefficient (r) values and Release kinetics of Ziprasidone Multi Unit GFDDS (Drug to polymer proportion- 1:1.5) with Single unit, Marketed sample "Zeldox" and

Pure Drug

\begin{tabular}{|c|c|c|c|c|c|c|c|c|c|c|}
\hline \multirow{2}{*}{ Formulation } & \multicolumn{2}{|c|}{ Zero Order } & \multicolumn{2}{|c|}{ First Order } & \multirow{2}{*}{\begin{tabular}{|l|} 
Diffusion \\
$R$ \\
\end{tabular}} & \multirow{2}{*}{\begin{tabular}{|l|} 
Erosion \\
$\mathbf{R}$ \\
\end{tabular}} & \multicolumn{2}{|c|}{ Pappas Equation } & \multirow{2}{*}{$\begin{array}{l}\mathbf{T}_{50} \\
\text { (Hours) }\end{array}$} & \multirow{2}{*}{$\begin{array}{l}\mathbf{T}_{80} \\
\text { ( Hours) }\end{array}$} \\
\hline & $\mathbf{K}_{\mathbf{O}}$ & $\mathbf{R}$ & $K_{1}$ & $\mathbf{R}$ & & & $\mathbf{R}$ & $\mathbf{N}$ & & \\
\hline F8 & 21.80 & 0.952 & 21.80 & 0.044 & 0.971 & 0.063 & 0.66 & 1.32 & 3.5 & 7 \\
\hline F9 & 35.32 & 0.951 & 35.32 & 0.023 & 0.968 & 0.028 & 0.54 & 1.55 & 1.8 & 4.5 \\
\hline F10 & 18.47 & 0.947 & 18.47 & 0.065 & 0.980 & 0.092 & 0.72 & 1.27 & 4.5 & 9 \\
\hline F11 & 17.91 & 0.991 & 0.059 & 0.031 & 0.910 & 0.056 & 0.80 & 1.36 & 7 & 11 \\
\hline F12 & 24.57 & 0.978 & 0.218 & 0.018 & 0.928 & 0.150 & 0.77 & 1.46 & 4.5 & 7 \\
\hline Single Unit & 16.60 & 0.962 & 0.089 & 0.99 & 0.946 & 0.003 & 0.975 & 1.992 & 5.5 & 11.8 \\
\hline Pure Drug & 428.9 & 1 & 5.435 & 1 & 1 & 1 & 0.996 & 1.187 & 0.3 & 0.75 \\
\hline ZELDOX & 225.25 & 0.971 & 0.221 & 0.92 & 0.992 & 0.49 & 0.993 & 1.196 & 0.1 & 0.4 \\
\hline
\end{tabular}

$\mathrm{K}_{\mathrm{O}}$ is the zero order release rate constant, $\mathrm{R}=$ correlation coefficient, $\mathrm{K}_{1}$ is the first order release rate constant. 
Theoretical release profile of a drug is constructed to check whether the formulations are releasing the drug similar to the predicted profile. Drug release from the optimized formulation F4 is compared with that of the theoretical release profile.

Table 13: Comparative Data of Theoretical Drug Release and F4 Formulation

\begin{tabular}{|l|l|l|}
\hline TIME (HRS) & THEORITICAL RELEASE & CUMULATIVE \% RELESE OF F7 \\
\hline $\mathbf{0}$ & 0 & 0 \\
\hline $\mathbf{2}$ & 28.3 & 17.43 \\
\hline $\mathbf{4}$ & 42.24 & 35.34 \\
\hline $\mathbf{6}$ & 56.1 & 62.6 \\
\hline $\mathbf{8}$ & 69.96 & 73.47 \\
\hline $\mathbf{1 0}$ & 79.86 & 87.32 \\
\hline $\mathbf{1 2}$ & 97.68 & 98.96 \\
\hline
\end{tabular}

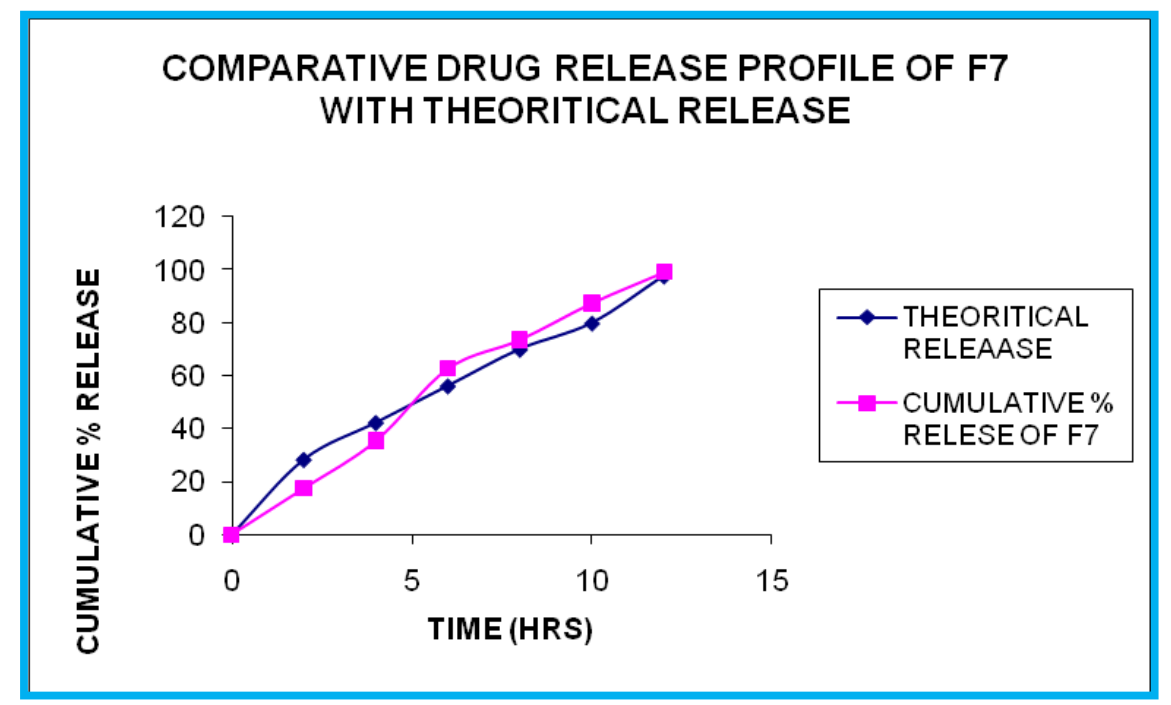

Figure 11: Comparative Drug Release Profile of Formulation with Theoretical Release

By comparing the dissolution profile it was found that the drug release from the optimized formulation is almost similar to that of the theoretical drug release. In order to establish the mechanism of drug release, the experimental data was fitted to five popular exponential equations.The drug release of Ziprasidone prepared from cellulose polymers (by wet granulation) and from the Lipoidal / fatty polymers ( by melt granulation) followed zero order kinetics which was clearly indicated by higher "r" values of Zero order release when compared $o$ those of first order release model.The relative contributions of drug diffusion and matrix erosion to drug release were further confirmed by subjecting the dissolution data to Higuchi model and Erosion model. It was found that all the formulations followed diffusion mechanism as indicated by their higher " $r$ " values

\section{Summary and Conclusion}

Ziprasidone multi unit granule GFDDS with controlled matrix cellulose and lipoidal polymers were prepared by different granulation techniques in the ratio of 1:1, 1:1.5 and 1:2.All the multi unit granule formulations (F1 to F12) prepared were evaluated for drug content and all the formulations had shown good results within the official limits.GFDDS prepared with Gelucire 43/01 had shown excellent buoyancy characteristics beyond 12 hours of study.The in 
vitro drug release studies of the entire prepared multi unit GFDDS were studied separately according to their proportions $(1: 1,1: 1.5$ and 1:2) using $0.1 \mathrm{~N} \mathrm{HCl}$ as medium in USP XXIV paddle type dissolution apparatus. The optimized formulation F4 was evaluated for its floating ability and in vitro drug release studies against single unit GFDDS prepared employing same polymer i.e., Gelucire 43/01with drug to polymer ratio of 1:3. By comparing the buoyant characteristics and release characteristics among F4 and single unit, single unit GFDDS had shown excellent floating ability for more than 12 hours, also the drug release was found to be $81 \%$ for 12 hours, by an unknown mechanism of drug release, very promising in vitro results were observed with multi unit floating formulations of Ziprasidone.

\section{References}

1. Jun C., William E., Haesun P., Kinam P., Gastric Retention Properties of Super porous Hydro gel Composites, Journal of Controlled Release, 64, 2000, 39-51.

2. Hwang S., Park H., Park K., Gastric retentive drug delivery systems, Critical Reviews in Therapeutic Drug Carrier System, 1998, 15, 243-284

3. Garg R., Gupta G., Progress in Controlled Gastro retentive Delivery Systems, The Tropical Journal of Pharmaceutical Research, 2008,7(3), 1055-1066.

4. Deshpande A., Rhodes C., Shah N.H, Malick A.W., Controlled release drug delivery systems for prolonged gastric residence: an overview, Drug Development of Indian Pharmacopeia, 22 (6), 1996, 531- 539.

5. Shweta A., Javed A., Alka A., Roop K., Sanjula B., Floating Drug Delivery Systems: $A$ Review; American Association of Pharmaceutical Scientists, 2005, 6(3), E372E386.

6. Aiman A., controlled release of Tramadol hydrochloride from matrices prepared using glycerin Behenat, European Journal of pharmaceutics and Biopharmaceutics, 2001, 52, 231-235.
7. Hilton A., Deasy PB., In vitro and in vivo evaluation of an oral sustained release floating dosage form of amoxicillin trihydrate, International Journal of Pharmacy, 1992, 86, 79-88.

8. Shyam S., Bhaskar C., Mahadik.K.R., and Anant P., Preparation and Evaluation of Diltiazem Hydrochloride-Glacier 43/01 Floating Granules Prepared by Melt Granulation, American Association of Pharmaceutical Scientists, 2004, 5(3).

9. Talukder R.., Fassihi R.., Jain NK., A new approach in gastro retentive delivery systems Indian Pharmacopeia of Drug Delivery System, 30(4): 405-412.

10. Bhaskar C., Shyam s., Mahadik K., Preparation and Evaluation of Floating Risedronate Sodium-Glacier 43/01 Formulations, Indian Pharmacopeia of Drug Delivery System, 2005, 31, 851-860.

11. Hwang S.J., Park H., Park K., Gastric retentive drug delivery systems, Critical Review in Therapeutic Drug Carrier Systems, 1998, 15, 243-284.

12. Clarke J.M., Newton G.M., Short M.D., Gastrointestinal transit of pellets of differing size and density, International Journal of Pharmacy, 100, 1993, 81-92.

13. Hwang S.J., Park H., Park K., Gastric retentive drug delivery systems, Critical Reviews in Therapeutic Drug Carrier Systems, 1998, 15, 243-284.

14. Lazaru J. and Cooper, Absorption, Testing, and Clinical Evaluation of Oral ProlongedAction Drugs Journal of Pharmaceutical Sciences, 58, 1253, 50, 715, 1961.

15. Wagner J.G.,Kinetic analysis of blood levels and urinary excretion in the absorptive phase after single doses of drug, Journal of Pharmaceutical Sciences, 58, 12531969.

16. Higuchi T.,Rate of Release of Medicaments from Ointment Bases Containing Drugs in Suspension, Journal of Pharmaceutical Sciences, 52, 1145, 1963.

17. Korsemeyer E., Gurny R., Doelke E.M., Buri P.,and Peppas N.A., International Journal of Pharmacy, 21, 25, 1983. 